\title{
Bioremediation Efficiency of Heavy Metal Contaminated Soil Using Earthworm Eisenia Fetida
}

\author{
Inesa Kniuipyte $\dot{1}^{1 *}$, Marius Praspaliauskas ${ }^{2}$, Jūratė Žaltauskaite ${ }^{3}$, Austra Dikšaitytè ${ }^{4}$ \\ ${ }^{1-3}$ Laboratory of Heat Equipment Research and Testing, Lithuanian Energy Institute, Kaunas, Lithuania \\ ${ }^{3-4}$ Department of Environmental Sciences, Vytautas Magnus University, Kaunas, Lithuania
}

Received 03 February 2020; accepted 20 April 2020

\begin{abstract}
The amount of sewage sludge (SS) used in agriculture and forest plantations is constantly growing in EU. It's known that even after various treatment methods some of contaminants still remain. The main risks of using SS in agriculture or forestry are related with hevy metals and organic pollutants content in SS. Heavy metals tend to acumulate in the environment and living organisms and may cause different adverse effects. Bioremediation using earthworms can be used to eliminate or mitigate the threat of heavy metals. Bioremediation is cheaper, requiries less energy and is more environmentally friendly than conventional physical or chemical remediation methods. But it's really important to evaluate bioremediation efficiency for SS, because there is evidence that nutrients in SS might improve efficiency of bioremediation. In this study earthworms Eisenia fetida were exposed for 9 weeks to SS amended soil. Earthworm mortality, growth and heavy metals $(\mathrm{Al}, \mathrm{Fe})$ accumulation were evaluated. The results showed that SS had a highly significant effect on earthworm mortality $(\mathrm{F}=4.98 ; \mathrm{p}<0.05)$ and growth $(\mathrm{F}=3.88-67.02 ; \mathrm{p}<0.05)$. Both metals concentrations in soil were signifficant $(\mathrm{p}<0.05)$ lower after vermi-remediation than after SS soil amendments. SS concentration had a significant effect to Al concentration accumulated in earthworm tissue $(\mathrm{F}=33.71 ; \mathrm{p}<0.05)$. This study demonstrated that bioremediation efficiency using E. fetida depends on concentrations of SS, survival and growth of earthworms.
\end{abstract}

Keywords: bioremediation, efficiency, earthworm, heavy metals.

\section{Introduction}

Sewage sludge is used as a fertilizer in agriculture and forestry because of it's high nitrogen and phosphorus concentrations. Sewage sludge, which meets quality standards and is used properly, has other advantages - promotes soil microbiological activity and microorganism counts, even at high levels of reclamation (Siebielec et al., 2018). Sewage sludge might increase plants biomass similar or even higher than mineral nitrogen fertilizers. Despite these advantages, sewage sludge also may contain various toxic inorganic and organic compounds, such as polychlorinated biphenyls (PCBs), absorbable organic halogens (AOX), pesticides, surfactants, drugs, nanoparticles and so on (Siebielska, 2014; Kończak \& Oleszczuk, 2018). Therefore, the use of sewage sludge in agriculture and forestry remains a significant waste management dilemma.

The quality of the sewage sludge has been improving in recent years due to advancing technology. However, even after various treatment methods, some of the contaminants still remain. One of the biggest problems from sewage sludge contamination are heavy metals because they are not biodegradable. They tend to accumulate in the environment and in living organisms and can cause many adverse effects (Charlton et al., 2016; Hadia-e-Fatima \& Ahmed, 2018). Soil contamination with heavy metals contributes to soil degradation, diminishing agricultural production, and poses a serious threat to feed and food safety (Maity et al., 2018). It also poses a critical risk not only to the state of ecosystems but also to humans (Sakizadeh \& Ghorbani, 2017; O'Connor et al., 2019). Reduction of heavy metal pollution and the cleaning of contaminated sites are becoming an increasingly important area of scientific research. However, traditional cleaning methods require a large amount of chemicals, energy use, and therefore have a large environmental footprint (Hou et al., 2018; Wang et al., 2019). Environmental engineering is increasingly used in the world to solve environmental pollution problems. Most commonly used biological methods of soil cleaning is vermi-remediation using earthworms.

Earthworms have great potential to improve the fertility and chemical properties of soil, as they mineralize basic nutrients, increase potassium and magnesium content, carbon circulation. During soil vermi-remediation,

${ }^{*}$ Corresponding author. E-mail: inesa.kniuipyte@lei.com

Copyright (C) 2020 The Author(s). Published by VGTU Press

This is an Open Access article distributed under the terms of the Creative Commons Attribution License (http://creativecommons.org/licenses/by/4.0/), which permits unrestricted use, distribution, and reproduction in any medium, provided the original author and source are credited. 
earthworms reduce the amount of heavy metals, while the amount of bioavailable nitrogen and phosphorus increase after vermi-remediation. Earthworms tend to bioaccumulate heavy metals in their tissues even at low concentrations so they could be used for bioremediation even at low pollution sites (Sinha et al., 2010; Babić et al., 2015; Huang et al., 2019). It's really important because heavy metals may decline soil quality and cause advert effects to organisms even if their concentrations are below legal limits (Singh \& Agrawal, 2008; Charlton et al., 2016; Uwizeyimana et al., 2017; Juan et al., 2019). Organic matter (OM) content, are crucial for bioremediation efficiency. OM is a source of energy for earthworms. If OM in the soil is low, earthworms are not able to digest the soil and, as a result, the toxicity of some metals (for example cadmium) might increase, leading to and increased earthworm mortality and disorder in reproduction or growth (Rorat et al., 2013; Haghparast et al., 2013; Irizar et al., 2015; Kończak \& Oleszczuk, 2018). However, data on OM impact on bioremediation are contradictory. In Mostafaii et al. (2016) study was found that organic matter has no effect on bioremediation. Some studies have shown that an increase of OM in soil contaminated with heavy metals can reduce the damaging effects of the metals (Haghparast et al., 2013).

Compost earthworm (Eisenia fetida) is a fast- growing, easy cocoon-producing species of earthworms (Rorat et al., 2013; Babić et al., 2015). It easily achieves a higher body weight compared to other earthworm species, e.g. Dendrobaena veneta and Eisenia andrei, which live in perishable organic matter. These 3 species are commonly used in vermicomposting converting organic waste into humus material used for soil improvement or fertilization or vermi-remediation (Morgan, 2010; Yadav \& Garg, 2011). The main aim of the study was to evaluate $\mathrm{Al}$ and $\mathrm{Fe}$ vermi-remediation efficiency from the sewage sludge amemnded soil.

\section{Materials and methods}

During the study, earthworms Eisenia fetida were exposed to five different concentrations of sewage sludge for 65 days: 5, 50, 100 and 200 t/ha in a phytochamber. Sewage sludge amendment doses were chosen according to the requirements of Lithuania legislation (LAND 20-2005) and doses usually found in the literature. Sewage sludge oncentrations were prepared in soil mixtures containing soil, perlite and sand (5:3:2). Detailed characteristics of origin sewage sludge could be found in Praspaliauskas et al. (2018). Ten washed and weighed adult earthworms were added to each container with $500 \mathrm{~g}$ prepared soil mixture. Three replications for each of sewage sludge concentration and control were used. Throughout experiment air temperature was $20 \pm 1{ }^{\circ} \mathrm{C}$, illumination 600 lux. Soil moisture was maintained at $50 \%$ the maximum soil water holding capacity (WHC) and controled using hand-set $\mathrm{HH} 2$ moisture meter with a depth of $6 \mathrm{~cm}$ (Delta-T Devices Ltd., Cambridge, UK) and adding required amount of deionized water. Every experiment week earthworms were additionaly fed with $0.5 \mathrm{~g}$ of oatmeal per 1 live earthworm to ensure their growth. Every exposition week earthworm growth and mortality were measured and recorded.

For $\mathrm{Al}$ and Fe concentrations determination earthworms were removed from the soil and cleaned, placed in Petri plates with moist filter paper for 24 hours to allow soil to be egested from their gut. Then earthworms were frozen $-80^{\circ} \mathrm{C}$ until heavy metal analysis. Weighed earthworms were digested in a Milestone Ethos One closed vessel microwave system with $\mathrm{HNO}_{3}-\mathrm{H}_{2} \mathrm{O}_{2}$ mixture. Air dried and grounded soil samples before and after vermi-remediation were digested in microwave with $\mathrm{HNO}_{3}-\mathrm{HCL}-\mathrm{HF}-\mathrm{H}_{3} \mathrm{BO}_{3}$ mixture. $\mathrm{Al}$ and $\mathrm{Fe}$ concentrations were measured with PerkinElmer® Optima ${ }^{\mathrm{TM}} 8000$ ICP-OES.

Soil $\mathrm{pH}$ and organic matter content was measured before and after vermi-remediation. Air dried grounded soil samples and KCL mixture was left for $4 \mathrm{~h}$ and then $\mathrm{pH}$ was measured using $\mathrm{pH}$ metter. Organic matter was estimated by loss-on-ignition (LOI) method. A soil sample was dried at $105{ }^{\circ} \mathrm{C}$ and then ashed at $400{ }^{\circ} \mathrm{C}$. The loss in weight between temperatures constitutes the organic matter content.

All the statistical analysis was carried out using Statistica software. For statistical analysis one-way analysis of variance (ANOVA) was used to assess sewage sludge concentration effect on analysed variables. Significant differences between different treatments were determined by T-test and the differences were consider statistically significant at $\mathrm{p}<0.05$.

\section{Results and discussion}

Chemical analysis of sewage sludge wich was used in this study showed that chemical elements did not exceed the permitted limits (Council Directive 86/278/EEC) so it can be used in agriculture and forestry. According to the requirements of the use of sewage sludge for fertilization and re-cultivation of heavy metal concentration $(\mathrm{mg} / \mathrm{kg})$, this sewage sludge depends to category I wich is the best (LAND 20-2005).

Earthworms mortality and growth have a direct impact on the efficiency of vermi-remediation. Analysis of variance (ANOVA) revealed that SS concentration had statistically significant effect on earthworm mortality $(\mathrm{F}=4.98$; $\mathrm{p}<0.05$ ). Sewage sludge did not cause a sudden acute effect on compost earthworms (Eisenia fetida) at concentrations below 100 t/ha. Only at the highest concentrations mortality was observed after the first week of the study: at $100 \mathrm{t} / \mathrm{ha}$ concentration mortality was close to $10 \%$ and in the treatment of $200 \mathrm{t} / \mathrm{ha}$ reached $50-60 \%$. The lowest mortality was found at 25 and $50 \mathrm{t} / \mathrm{ha}(10-20 \%)$. Linear relationship between mortality of compost earthworms and sewage sludge concentration in soil was determined $\left(R^{2}=0.82 ; \mathrm{p}<0.05\right)$. 


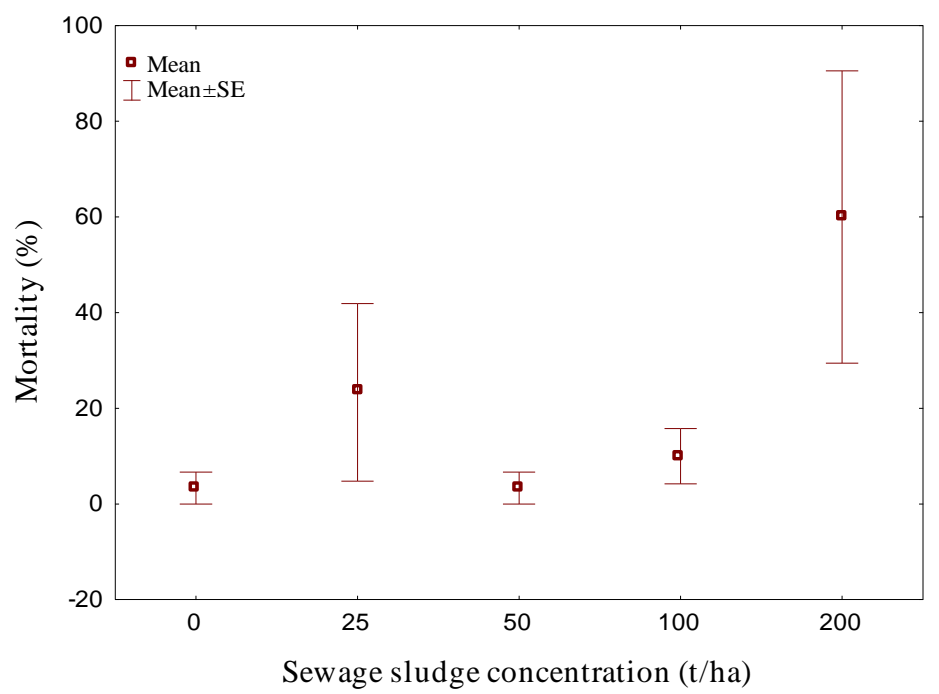

Figure 1. Earthworms mortality in different sewage sludge concentrations

The results showed that after 65 days the highest mortality percentage $(60 \%)$ was recorded at the highest SS concentration of $200 \mathrm{t} / \mathrm{ha}$ (Figure 1). This can be explained by the long-term (chronic) toxic effects of sewage sludge (heavy metals), which possibly exceeded the protective capacity of the antioxidant system enzymes (Duo et al., 2019). Moreover, in the treatment with the highest SS concentration the effect on earthworm behaviour was also observed as earthworms tried to avoid to penetrat into the contaminated soil. This behaviour might also increase the impaired earthworm growth or even death. After 4 weeks, visible high pressure of the coelomocytic fluid and earthworm tissue damage occurred due to the chronic effects of sewage sludge (Rorat et al., 2013). Other researches findings show that earthworms should be removed from soil in the vermi-remediation process before week fifteen because during this stage the excretion of heavy metals from earthworms occurred (Azizi et al., 2013).

Weight change is a very sensitive indicator that earthworms experience stress. This response can act as a defense mechanism by which earthworms reduce food consumption and reduce metabolic rate to avoid the harmful effects of heavy metals, e.g. - oxidative stress (Duo et al., 2019). Data analysis (ANOVA) showed that sewage sludge concentration had a statistically significant effect on compost earthworm growth $(F=3.87-67.02 ; p<0.05)$ at 1-7 weeks of study, however, there was no statistically significant effect on growth at $8-9$ weeks $(\mathrm{F}=3.87-3.96$; $\mathrm{p}>0.05$ ). The biggest growth was recorded at $25 \mathrm{t} / \mathrm{ha}$ concentration and it was by $16 \%$ bigger but not statisticaly significant ( $>0.05$ ) than control group, by 11-36\% higher than in the treatments with 50-200 t/ha concentrations (Figure 2) and statisticaly significant difference found between 25 and 100-200 t/ha treatments. Our experiment results, as well as other scientific studies, show that low concentrations of sewage sludge in soil increase the weight gain of earthworms statisticaly significantly (Rorat et al, 2013). Because small amounts of sludge are a very good source of nutrients that support their growth for at least 8 weeks, however, high concentrations negatively impact because of heavy metals and other hazardous contaminants (Kończak, 2018).

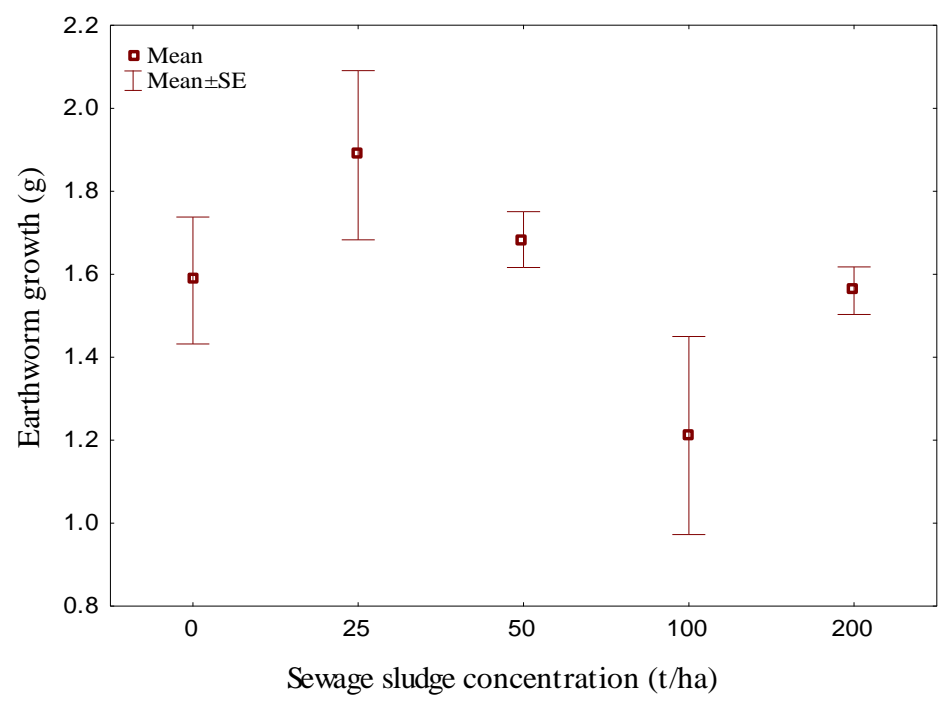

Figure 2. Earthworms growth in different sewage sludge concentrations 
Sewage sludge have significant effect to both metals concentrations in soil before vermi-remediation, but it was bigger to $\mathrm{Fe}(\mathrm{F}=6259.514 ; \mathrm{p}<0.05)$ than $\mathrm{Al}(\mathrm{F}=216.151 ; \mathrm{p}<0.05)$, but SS didn't have significant effect to both heavy metals concentration in soil after process. Heavy metal concentration analysis showed that after vermi-remediation Fe concentrations was statistically significantly higher than Al both in soil (Figure 3) and earthworm tissue (Figure 4). Many scientific studies proved that earthworms can readily bioaccumulate heavy metals and other pollutants because of direct contact with soil, both externally via absorption through the skin and internally by adsorption to the digestive tract (Hobbelen et al., 2006; Spurgeon \& Hopkin, 1996). T-test showed that concentrations of both metals (Fe and $\mathrm{Al})$ in soil was signifficant lower $(\mathrm{p}<0.05)$ after vermi-remediation than before in all sewage sludge treatments. Sewage sludge influenced heavy metals accumulation in earthworm tissue differently, it also depended on the treatment concentration.

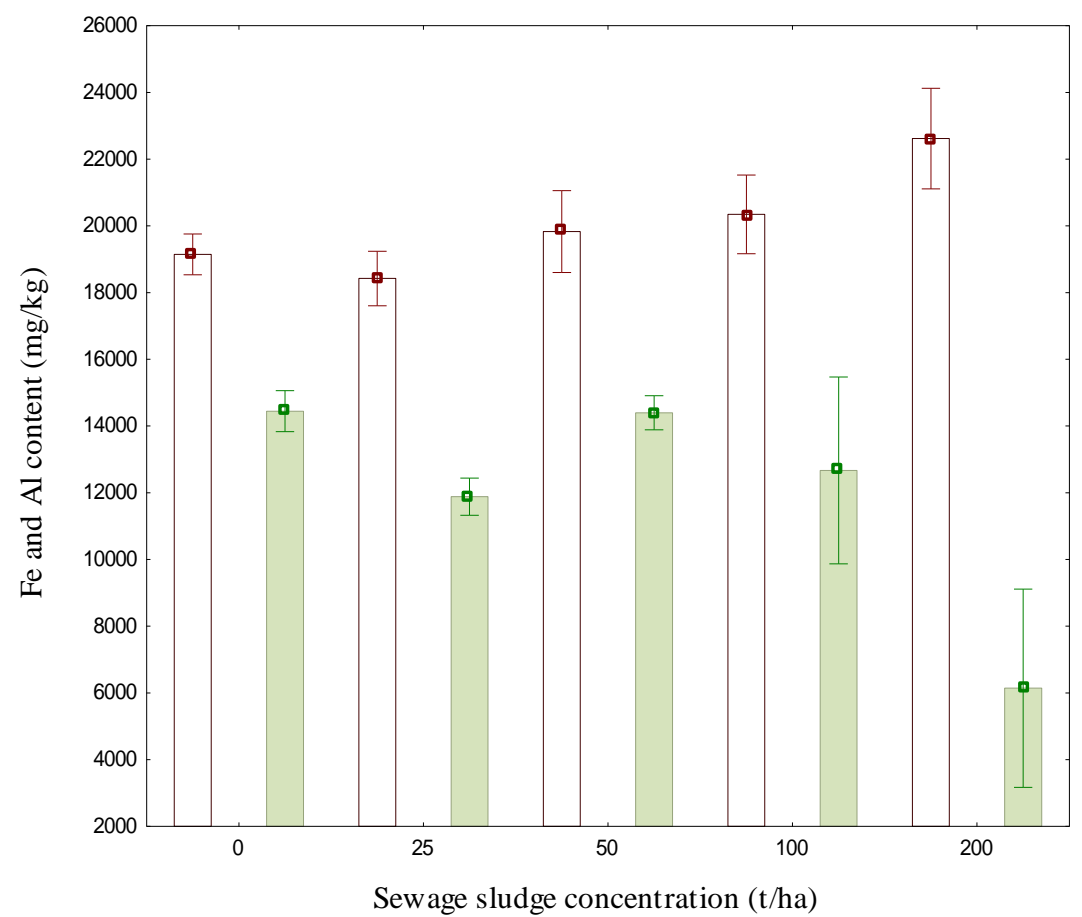

Figure 3. $\mathrm{Al}$ and $\mathrm{Fe}$ content in soil with different sewage sludge concentrations after vermi-remediation

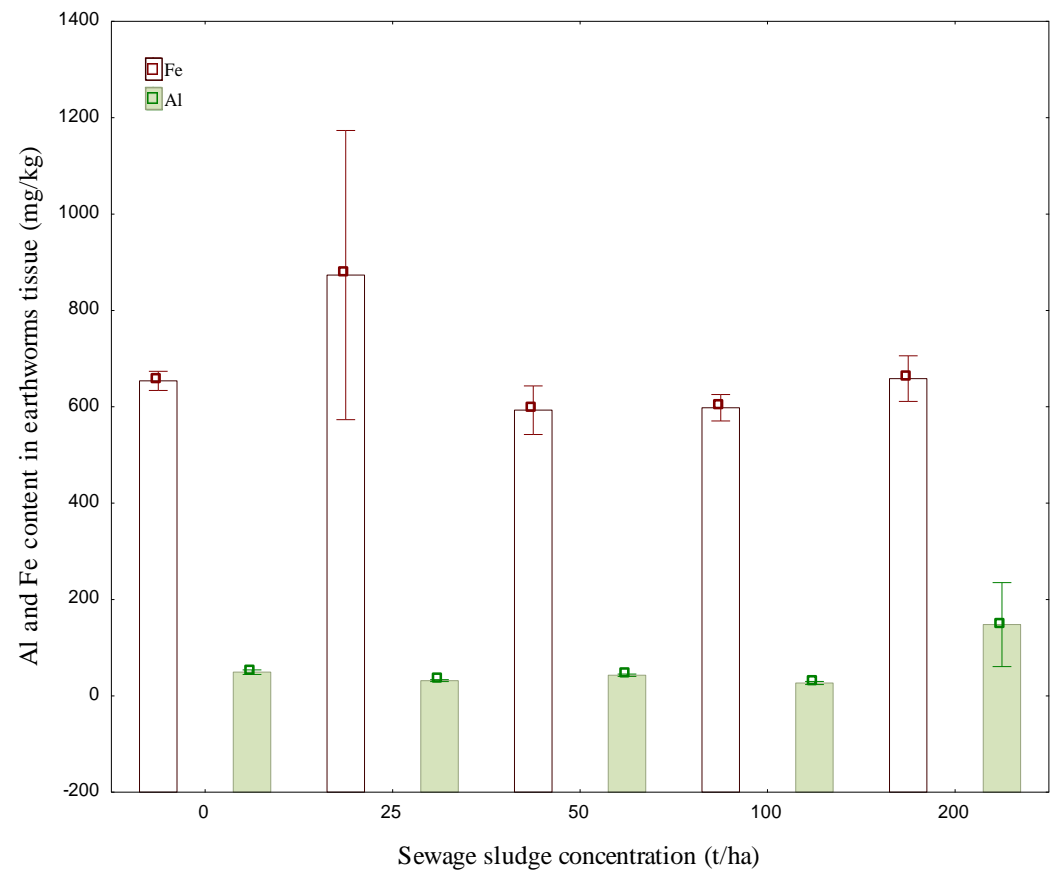

Figure 4. $\mathrm{Al}$ and $\mathrm{Fe}$ content in earthworm tissue at different sewage sludge concentrations after vermi-remediation 
SS concentration had no statistically significant effect to Fe accumulation in earthworm tissue which was biggest in lowest SS concentration treatment which was $25 \mathrm{t} /$ ha (Figure 4). Sewage sludge concentration had significant effect to $\mathrm{Al}$ concentration accumulated in earthworm tissue $(\mathrm{F}=33.707 ; \mathrm{p}<0.05)$. There was statistically significant and positive correlation $(0.806 ; \mathrm{p}<0.05)$ between $\mathrm{Al}$ acumulation in earthworm tissue and sewage sludge concentration. Lowest Al concentration in soil after vermi-remediation was found in highest SS concentration treatment (200 t/ha) in which was highest $\mathrm{Al}$ accumulation in earthworm tissue, it can be explained by effective remediation process. But it's important to mention that by increasing Al concentration accumulated in earthworm tissue earthworm mortality increases statiscally significant $(\mathrm{p}<0.05)$, for this reason toxic heavy metals effect to earthworms and vermi-remediation process should be kept in mind.

Most critical environmental factors that regulate earthworm population are soil type and organic matter content, $\mathrm{pH}$ and moisture. Organic matter content might impact vermi-remediation efficiency, because it's a source of nutirents for earthworms (Rorat et al., 2013; Irizar et al., 2015; Hagkparast et al., 2013). Sewage sludge can improve soil quality including OM content, statistic analysis showed that sewage sludge had a significant effect on OM content both before $(\mathrm{F}=47.958 ; \mathrm{p}<0.05)$ and after $(\mathrm{F}=67.507 ; \mathrm{p}<0.05)$ vermi-remediation. Biggest organic matter content was found in the treatment with the highest sewage sludge concentrations (100 and $200 \mathrm{t} / \mathrm{ha}$ ). Lowest OM content was found in control case. T-test showed that organic matter content was statisticaly significant bigger before vermi-remediation than after in all sewage sludge concentrations $(\mathrm{p}<0.05)$. In our study sewage sludge increased organic matter content in soil before vermi-remediation improving soil quality. After vermi-remediation OM content was lower than before, because OM is a food source for earthworms (Kończak \& Oleszczuk, 2018; Rorat et al., 2013). Organic matter content didn't have significant correlation ( $p>0.05)$ with both metals concentrations in soil and Fe accumulation in earthworms tissue after vermi-remediation, neither with mortality or growth $(p>0.05)$. It only had significant correlation $(\mathrm{p}<0.05)$ with $\mathrm{Al}$ concentration in earthworm tissue after vermi-remediation. OM content in soil affected heavy metals vermi-remediation differently, so further analysis in this area is strongly requested.

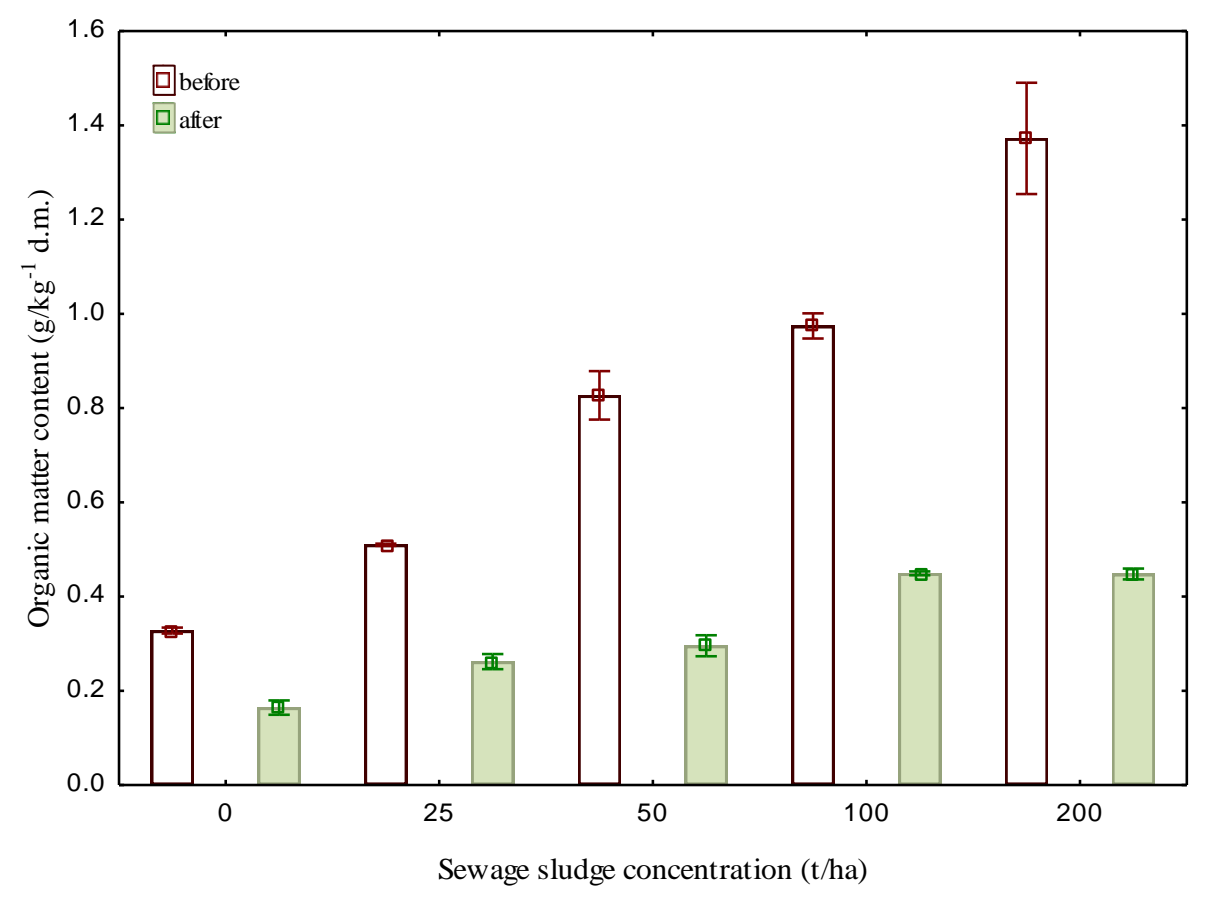

Figure 5. Soil organic matter content in different sewage sludge concentrations before and after vermi-remediation

Soil $\mathrm{pH}$ is important factor influencing heavy metal solubility, bioavailability and their toxic effects to organizms. Earthworms are sensitive to soil $\mathrm{pH}$. In our experiment soil $\mathrm{pH}$ changed both from sewage sludge application and vermi-remediation process but it still varies close to earthworms optimal soil $\mathrm{pH}$ range which varies from 6.0 to 7.0 (OECD, 1984; ISO, 2012; ASTM, 2004). SS concentration cause significant effect $(\mathrm{p}<0.05)$ on soil $\mathrm{pH}$ both before and after vermi-reme- diation process. Sewage sludge aplication statistically significantly reduced soil $\mathrm{pH}$. It's known that as soil $\mathrm{pH}$ decreases, the amount of $\mathrm{H}^{+}$increases the concentration of many heavy metals in soil solution. Researches have shown that some metal cations are more soluble and available in low $\mathrm{pH}$ soil solutions. Lowered soil pH doesn't increase activity of all heavy metals - the solubility of cations increases at lower pH values, when anions are more soluble in alkaline $\mathrm{pH}$ ranges due to sorption in solid soil phases (Adamczyk- Szabela et al., 2015; Sheoran et al., 2016). But in this study there was no statistically significant relationship found between soil $\mathrm{pH}$ changes and heavy metals ( $\mathrm{Fe}$ and $\mathrm{Al}$ ) accumulation in earthworms tissue. Lowest soil $\mathrm{pH}$ was found in the highest 
sewage sludge concentrations (100 and $200 \mathrm{t} / \mathrm{ha}$ ). Highest $\mathrm{pH}$ in soil was measured in lowest sewage sludge concentration ( $25 \mathrm{t} / \mathrm{ha}$ ) and control. After soil passes through the earthworm gut, soil $\mathrm{pH}$ can be adjustified to $\sim \mathrm{pH} 7$ (Hand, 1988; OECD, 1984, because of that vermi-remediation influence soil pH. T-test showed that soil $\mathrm{pH}$ was statisticaly significant $(\mathrm{p}<0.05)$ bigger after vermi-remediation than before in all sewage sludge concentrations indicating that vermi-remediation had a positive effect and soil $\mathrm{pH}$ increased during this process. Further analysis showed that organic matter content had significant effect on $\mathrm{pH}$ before $(\mathrm{F}=238.216 ; \mathrm{p}<0.05)$ and after vermi-remediation $(\mathrm{F}=193.92 ; \mathrm{p}<0.05)$.

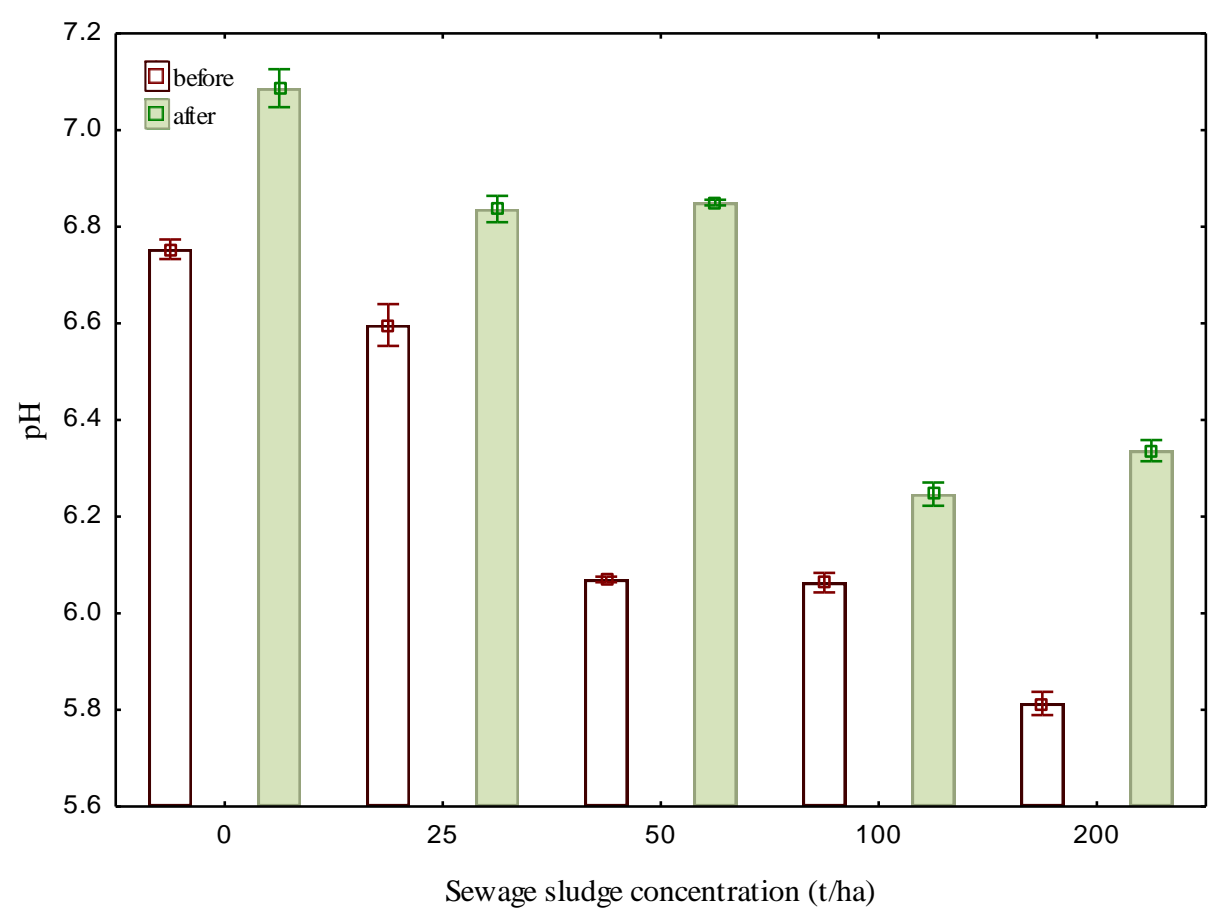

Figure 6. Soil $\mathrm{pH}$ in different sewage sludge concentrations before and after vermi-remediation

\section{Conclusions}

This study demonstrated that bioremediation efficiency using E. fetida depends on sewage sludge concentrations, survival and growth of earthworms. Results showed that vermi-remediation is a reliable way to clean soil contamination for both metals ( $\mathrm{Al}$ and $\mathrm{Fe}$ ), because after vermi-remediation process both metals concentrations in soil was statistically significant lower than before in all SS treatments $(25,50,100$ and $200 \mathrm{t} / \mathrm{ha})$. Sewage sludge did not cause a sudden acute effect on compost earthworms at concentrations below 100 t/ha. However sewage sludge concentration affected bioremediation efficiency of $\mathrm{Al}$ and $\mathrm{Fe}$ differently. Largest $\mathrm{Al}$ concentration accumulated in earthworm tissue was at highest SS concentration treatment $(200 \mathrm{t} / \mathrm{ha})$ in which the largest earthworms mortality also occurred so it might have negative impact on bioremediation efficiency for a longer cleaning period, because total remediated heavy metal content would be lower as a result of the reduced number of individuals. Largest earthworms growth and $\mathrm{Fe}$ accumulation in tissue was biggest in lowest sewage sludge concentration $(25 \mathrm{t} / \mathrm{ha})$. SS concentration have statistically significant effect just to Al accumulation. This might happen, because there are statistically significant and positive correlation between $\mathrm{OM}$ content in soil and $\mathrm{Al}$ accumulation in earthworm tissue. Vermi-remediation prosses caused statisticaly significant decrease in OM content and increased $\mathrm{pH}$ value in all SS concentrations.

\section{References}

Adamczyk-Szabela, D., Markiewicz, J., \& Wolf, W. M. (2015). Heavy metal uptake by herbs. IV. Influence of soil pH on the content of heavy metals in Valeriana officinalis L. Water Air Soil Pollut, 226(4), 106. https://doi.org/10.1007/s11270-015-2360-3

ASTM. (2004). Standard guide for conducting laboratory soil toxicity or bioaccumulation tests with the lumbricid earthworm Eisenia fetida and the enchytraeid potworm Enchytraeus albidus. US.

Azizi, A. B., Lim, M. P. M., Noor, Z. M., \& Abdullah, N. (2013). Vermiremoval of heavy metal in sewage sludge by utilising Lumbricus rubellus. Ecotoxicology and Environmental Safety, 90, 13-20. https://doi.org/10.1016/j.ecoenv.2012.12.006 
Babić, S., Dragun, Z., Sauerborn Klobučar, R., Ivanković, D., Bačić, N., Fiket, Ž., Barišić, J., Krasnići, N., Strunjak-Perović, I., Popović, N. T., \& Čož-Rakovac, R. (2015). Indication of metal homeostasis disturbance in earthworm Eisenia fetida after exposure to semi-solid depot sludge. Science of the Total Environment, 526, 127-135. https://doi.org/10.1016/j.scitotenv.2015.04.056

Charlton, A., Sakrabani, R., Tyrrel, S., Casado, M. R., McGrath, S. P., Crooks, B., Cooper, P., \& Campbell, C. D. (2016). Long-term impact of sewage sludge application on soil microbial biomass: An evaluation using meta-analysis. Environmental Pollution, 219, 1021-1035. https://doi.org/10.1016/j.envpol.2016.07.050

Council of the European Communities. (1986). Council Directive 86/278/EEC of 12 June 1986 on the protection of the environment, and in particular of the soil, when sewage sludge is used in agriculture.

Duo, L., Yin, L., Zhang, C., \& Zhao, S. (2019). Ecotoxicological responses of the earthworm Eisenia fetida to EDTA addition under turfgrass growing conditions. Chemosphere 220, 56-60. https://doi.org/10.1016/j.chemosphere.2018.12.106

Hadia-e-Fatima, \& Ahmed, A. (2018). Heavy metal pollution - A mini review. Bacteriology \& Mycology: Open Access, 6(3), 179-181. https://doi.org/10.15406/jbmoa.2018.06.00199

Haghparast, R. J., Golchin, A., \& Kahneh, E. (2013). Effect of different cadmium concentrations on growth of Eisenia fetida in a calcareous soil. Journal of Water and Soil, 27, 24-35.

Hobbelen, P. H. F., Koolhaas, J. E., \& Van Gestel, C. A. M. 2006. Bioaccumulation of heavy metals in the earthworms Lumbricus rubellus and Aporrectodea caliginosa in relation to total and available metal concentrations in field soils. Environmental Pollution, 144(2), 639-646. https://doi.org/10.1016/j.envpol.2006.01.019

Hou, D., Song, Y., Zhang, J., Hou, M., OConnor, D., \& Harclerode, M. (2018). Climate change mitigation potential of contaminated land redevelopment: A city-level assessment method. Journal of Cleaner Production, 171, 1396-1406. https://doi.org/10.1016/j.jclepro.2017.10.071

Huang, Y., Wang, L., Wang, W., Li, T., He, Z., \& Yang, X. (2019). Current status of agricultural soil pollution by heavy metals in China: A meta-analysis. Science of The Total Environment, 651(Part 2), 3034-3042. https://doi.org/10.1016/j.scitotenv.2018.10.185

International Organization for Standardization. (2012). Soil quality - Effects of pollutants on earthworms - Part 1: Determination of acute toxicity to Eisenia fetida/Eisenia andrei (ISO 11268-1:2012).

Irizar, A., Rodríguez, M., Izquierdo, A., Cancio, I., Marigómez, I., \& Soto, M. (2015). Effects of soil organic matter content on cadmium toxicity in Eisenia Fetida: Implications for the use of biomarkers and standard toxicity tests. Archives of Environmental Contamination and Toxicology, 68, 181-192. https://doi.org/10.1007/s00244-014-0060-4

Yadav, A., \& Garg, V. (2011). Industrial wastes and sludges management by vermicomposting. Reviews in Environmental Science and Bio/Technology, 10, 243-276. https://doi.org/10.1007/s11157-011-9242-y

Juan, C. S.-H, Juan, M. R., Andrés, M. A., Alessio, M., \& Ximena, A. C. (2019). Assessing biochar impact on earthworms: Implications for soil quality promotion. Journal of Hazardous Materials, 366, 582-591. https://doi.org/10.1016/j.jhazmat.2018.12.032

Kończak, M., \& Oleszczuk, P. (2018). Application of biochar to sewage sludge reduces toxicity and improve organisms growth in sewage sludge-amended soil in long term field experiment. Science of the Total Environment, 625, 8-15. https://doi.org/10.1016/j.scitotenv.2017.12.118

Lietuvos Respublikos aplinkos ministerija. (2005). Requirements for the use of sewage sludge for fertilization and recovery (LAND 20-2005) (in Lithuanian).

Maity, S., Banerjee, R., Goswami, P., Chakrabarti, M., \& Mukherjee, A. (2018). Oxidative stress responses of two different ecophysiological species of earthworms (Eutyphoeus waltoni and Eisenia fetida) exposed to Cd-contaminated soil. Chemosphere, 203, 307-317. https://doi.org/10.1016/j.chemosphere.2018.03.189

Morgan, A. J. (2010). Heavy metals, earthworms, and vermicomposts. In C. A. Edwards, N. Q. Arancon, R. L. Sherman (Eds.), Vermiculture Technology (Chapter 17, pp. 263-285). Boca Raton. https://doi.org/10.1201/b10453-18

Mostafaii, G. R., Aseman, E, Asgharnia, H., Akbari, H., Iranshahi, L, \& Sayyaf, H. (2016). Efficiency of the earthworm Eisenia fetida under the effect of organic matter for bioremediation of soils contaminated with cadmium and chromium. Brazilian Journal of Chemical Engineering, 33(4), 827-834. https://doi.org/10.1590/0104-6632.20160334s20150230

O’Connor, D., Hou, D., Ok, Y. S., Mulder, J., Duan, L., Wu, Q., Wang, S., Tack, F. M. G., \& Rinklebe, J. (2019). Mercury speciation, transformation, and transportation in soils, atmospheric flux, and implications for risk management: A critical review. Environment International, 126, 747-761. https://doi.org/10.1016/j.envint.2019.03.019

OECD. (1984). OECD guidelines for testing of chemicals: Earthworm, acute toxicity test, TG 207. Organisation for Economic Co-operation and Development. Paris, France.

Praspaliauskas, M., Pedišius, N., \& Striūgas, N. (2018). Elemental migration and transformation from sewage sludge to residual products during the pyrolysis process. Energy \& Fuels, 32(4), 5199-5208. https://doi.org/10.1021/acs.energyfuels.8b00196

Rorat, A., Kacprzak, M., Vandenbulcke, F., \& Płytycz, B. (2013). Soil amendment with municipal sewage sludge affects the immune system of earthworms Dendrobaena veneta. Applied Soil Ecology, 64, 237-244. https://doi.org/10.1016/j.apsoil.2012.12.017

Sakizadeh, M., \& Ghorbani, H. (2017). Concentration of heavy metals in soil and staple crops and the associated health risk. Archives of Hygiene Sciences, 6(4), 303-313. https://doi.org/10.29252/ArchHygSci.6.4.303

Sheoran, V., Sheoran, A. S., \& Poonia, P. (2016). Factors affecting phytoextraction: a review. Pedosphere, 26(2), 148-166. https://doi.org/10.1016/S1002-0160(15)60032-7 
Siebielec, G., Siebielec, S., \& Lipski, D. (2018). Long-term impact of sewage sludge, digestate and mineral fertilizers on plant yield and soil biological activity. Journal of Cleaner Production, 187, 372-379. https://doi.org/10.1016/j.jclepro.2018.03.245

Siebielska, I. (2014). Comparison of changes in selected polycyclic aromatic hydrocarbons concentrations during the composting and anaerobic digestion processes of municipal waste and sewage sludge mixtures. Water Science \& Technology, 70(10), 1617-1624. https://doi.org/10.2166/wst.2014.417

Singh, R. P., \& Agrawal, M. (2008). Potential benefits and risks of land application of sewage sludge. Waster Management, 28(2), 347-358. https://doi.org/10.1016/j.wasman.2006.12.010

Sinha Rajiv, K., Herat, S., Bharambe, G., \& Brahambhatt, A. (2010). Vermistabilization of sewage sludge (biosolids) by earthworms: Converting a potential biohazard destined for landfill disposal into a pathogen-free, nutritive and safe biofertilizer for farms. Waste Management \& Research, 28(10), 872-81. https://doi.org/10.1177/0734242X09342147

Spurgeon, D. J., \& Hopkin, S. P. (1996). Effects of variations of the organic matter content and pH of soils on the availability and toxicity of $\mathrm{Zn}$ to the earthworm Eisenia fetida. Pedobiologia, 40, 80-96.

Uwizeyimana, H., Wanga, M., Chena, W., \& Khana, K. (2017). The eco-toxic effects of pesticide and heavy metal mixtures towards earthworms in soil. Environmental Toxicology and Pharmacology, 55, 20-29. https://doi.org/10.1016/j.etap.2017.08.001

Wang, Y., O’Connor, D., Shen, Z., Lo, I. M. C., Tsang, D. C. W., Pehkonen, S., Pu, S., \& Hou, D. (2019). Green synthesis of nanoparticles for the remediation of contaminated waters and soils: Constituents, synthesizing methods, and influencing factors. Journal of Cleaner Production, 226, 540-549. https://doi.org/10.1016/j.jclepro.2019.04.128 